\title{
TOTAL CORDECTOMY IN A PATIENT WITH PRIMARY DORSO-LUMBAR GLIOBLASTOMA MULTIFORME AND PARAPLEGIA: A CASE REPORT
}

\author{
AHMED A. M. ABDELHAFEEZ ${ }^{1}$, WAEL IBRAHIM², \\ AHMED MOUSTAFA WEDN ${ }^{3}$, WESSAM ELSHERIEF ${ }^{1}$ \\ ${ }^{1}$ Department of Clinical Oncology, Kasralainy Hospital, Faculty of Medicine, Cairo University; Cairo, Egypt; \\ ${ }^{2}$ Department of Neurology, Kasralainy, Faculty of Medicine, Cairo University, Cairo, Egypt; \\ ${ }^{3}$ Department of Critical Care, Kasralainy, Faculty of Medicine, Cairo University, Cairo, Egypt
}

\section{Summary}

In this paper, we report a case of a 57-year-old male patient with non-metastatic dorso-lumbar glioblastoma multiforme (GBM) who underwent total cordectomy followed by chemoradiotherapy. Primary dorso-lumbar GBM is a rare finding. Despite the total cordectomy and chemoradiotherapy treatment, recurrence occurs mostly within a short time with poor prognosis.

KEYWORDS: glioblastoma multiforme, magnetic resonance, total cordectomy

\section{TOTALNA KORDEKTOMIJA U PACIJENTA S PRIMARNIM DORZOLUMBARNIM MULTIFORMNIM GLIOBLASTOMOM I PARAPLEGIJOM - PRIKAZ SLUČAJA}

\section{Sažetak}

Muškarac u dobi od 57 godina s nemetastatskim multiformnim dorzolumbalnim glioblastomom (GBM) podvrgnut je totalnoj kordektomiji i kemoradioterapiji. Primarni dorzolumbalni GBM se rijetko nalazi. Unatoč totalnoj kordektomiji i kemoradioterapiji bolest se vraća s lošom prognozom u kratkom vremenskom razdoblju.

KLJUČNE RIJEČI: multiformni glioblastom, magnetska rezonancija, totalna kodektomija

\section{INTRODUCTION}

In adults, the most common malignant primary brain tumor is glioblastoma multiforme (GBM) (1). On the spinal level, GBM represents a minority of all spinal cord tumors and only $7.5 \%$ of all intramedullary gliomas (2), with few studies reporting intracranial dissemination (3). In $60 \%$ of spinal GBM cases, the tumor was detected in cervical or cervicothoracic regions, indicating that these regions are the most common sites for spinal
GBM (4). In contrast to supratentorial GBM, spinal glioblastoma (GB) is usually present during the second and third decades of life (5). However, cerebral and spinal GB are similar in terms of histopathological features (6). Although most spinal GBM cases experienced short-term survival, some cases experienced long-term survival of over 18 months (6). We report here a patient with nonmetastatic dorso-lumbar GBM who underwent total cordectomy followed by chemoradiotherapy with local recurrence 15 months postoperatively. 


\section{CASE REPORT}

A 57-year-old male had a progressive motor weakness of both lower limbs and was mobile with the aid of a cane. The patient also had hypertension and had been previously treated with sofosbuvir for hepatitis C virus (HCV). In June 2016, he was referred to our clinic in Kasr Al Aini Hospital with magnetic resonance (MR) imaging of the thoracolumbar vertebra showing only spondylodegenerative changes in L4-L5 disc.

In December 2016, the condition progressed as the patient developed urine and stool incontinence. Moreover, the neurological examination revealed worsening of motor functions with weakness of both lower limbs grade 1 (with the patient confined to a wheelchair) and jacket sensory loss at the lower dorsal level with no neurologic abnormality of the upper limbs. Accordingly, MRI dorso-lumbar spine with contrast revealed intramedullary mass lesion with low T1 and intermediate T2 signal intensity and rather heterogeneous contrast enhancement; this lesion was confined to level T11-L1 with compression of conus medullaris (CM), causing fusiform expansion of the cord (Figure 1). Workup for extra-neuronal metastases was done including post-contrast computed tomography (CT) scan of the chest, non-contrast CT abdomen, and pelvis, 99mTc with methylene diphosphonate (TC-MDP) bone scan, in addition to MR brain with contrast and all of them were negative. In December 2016, the patient underwent total cordectomy for the tumor. An irregular greyish red mass measuring $5 \times 5 \mathrm{~cm}$ was sent for histopathology, which revealed the following results

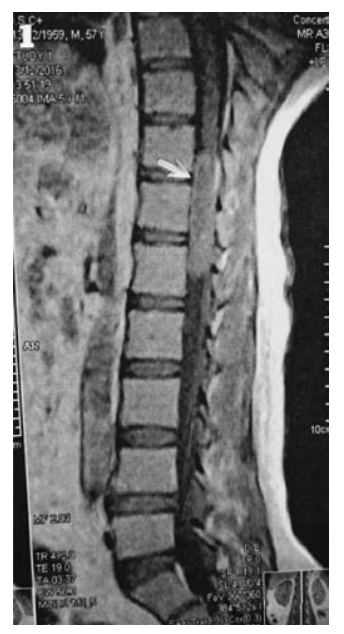

Figure 1: MR dorso-lumbar spine with contrast sagittal T1, showing intramedullary mass lesion (arrow) with low $\mathrm{T} 1$ and intermediate $\mathrm{T} 2$ signal intensity and rather heterogenous contrast enhancement, confined to level T11-L1 with compression of conus medullaris.
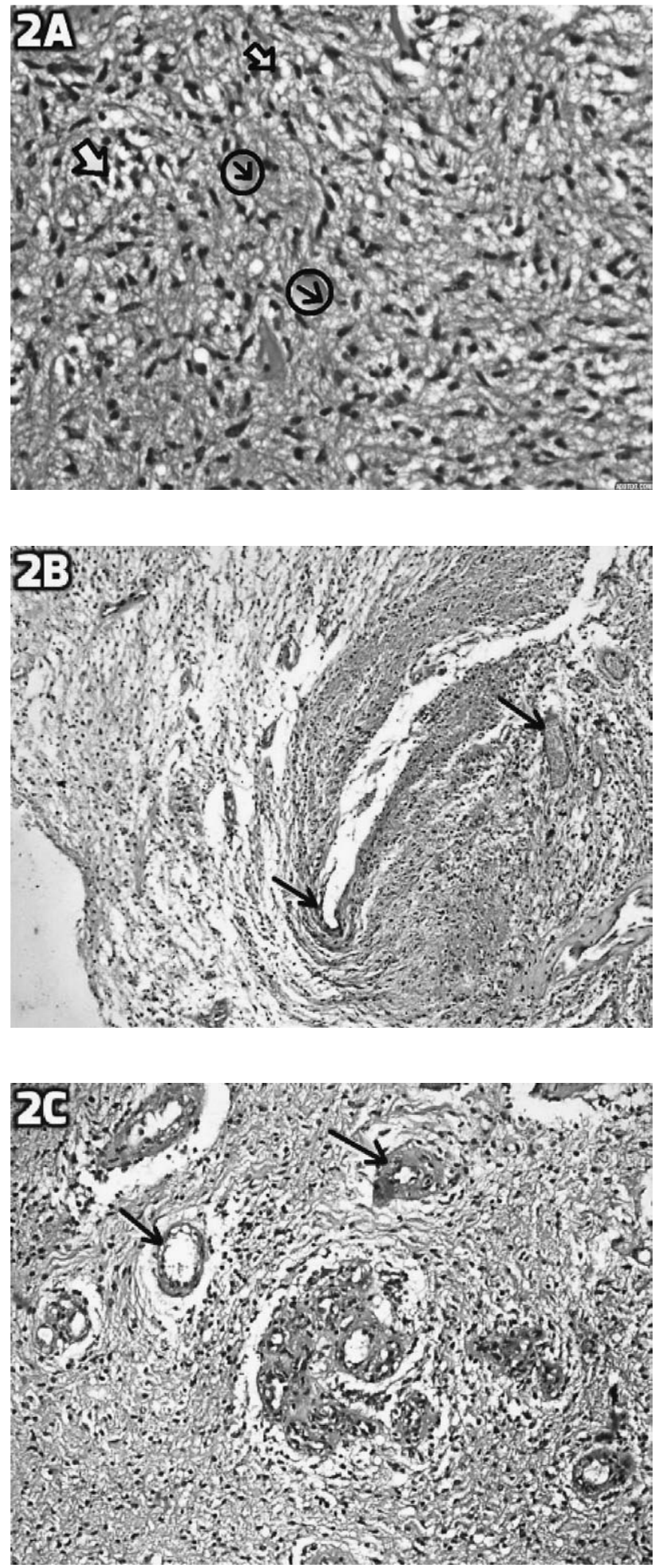

Figure 2: (a) astrocytes with moderate nuclear polymorphism (un-circled arrows) scattered within the eosinophilic fibrillary matrix (circled arrows), (b) palisading necrosis, (c) vascular proliferation. 
(Figure 2): astrocytes with moderate nuclear polymorphism were scattered within the eosinophilic fibrillary matrix (Figure 2a). There was also palisading necrosis (Figure $2 b$ ) and vascular proliferation (Figure 2c). A diagnosis of Governing Body Documentation - World Health Organization (GB WHO) grade IV was made. MR dorso-lumbar spine was done one month postoperatively, which shows spinal laminectomy and debulking of the tumor with reduced size and internal cystic changes. Additionally, the surgical gap was sealed by granulation tissue with no evidence of active infection or pseudo-meningocele formation. In turn, no further surgical procedures were performed.

\section{Postoperative Course}

After confirmation of diagnosis, the patient underwent focal radiotherapy for the dorso-lumbar region (45Gy in 25 fractions/5 weeks) and concomitant temozolomide, then adjuvant therapy for six months. The patient was discharged and scheduled for regular follow-up at the outpatient oncology clinic. No side effects were detected during the postoperative treatment.

In April 2017, follow-up MR dorso-lumbar spine with gadolinium $(\mathrm{Gd})$ enhancement was done showing a stationary course of patient condition with no new masses or lesion. Granulation tissue was seen creeping across the thecal sac; this tissue was inseparable from the $\mathrm{CM}$ as well as the distal thecal nerves (Figure 3). Regarding the neurological status, no improvement was noticed in the motor weakness, and the patient was still confined to the wheelchair.

During the postoperative follow-up period of 15 months, local recurrence was detected on MR dorso-lumbar spine with Gd enhancement in the form of contrast-enhancing ill-defined soft tissue lesion in the spinal cord opposite to D10 down to L1 vertebral bodies. MRI brain with Gd was normal, and the patient was planned for palliative chemotherapy, but he refused.

\section{DISCUSSION}

Of all central nervous system tumors, primary spinal cord neoplasms account for only $2-4 \%$, with the spinal GBM representing only $1.5 \%$ of all spinal cord tumors. Spinal cord GBM has an aggressive course in which mortality usually results from cerebral metastases or complications of progressive spinal cord affection. With the introduction of temozolomide as an adjuvant therapy to surgery and radiotherapy, the overall survival rates have risen (7).

The review of literature done by Morais and his colleagues (4) summarizes the therapeutic op-

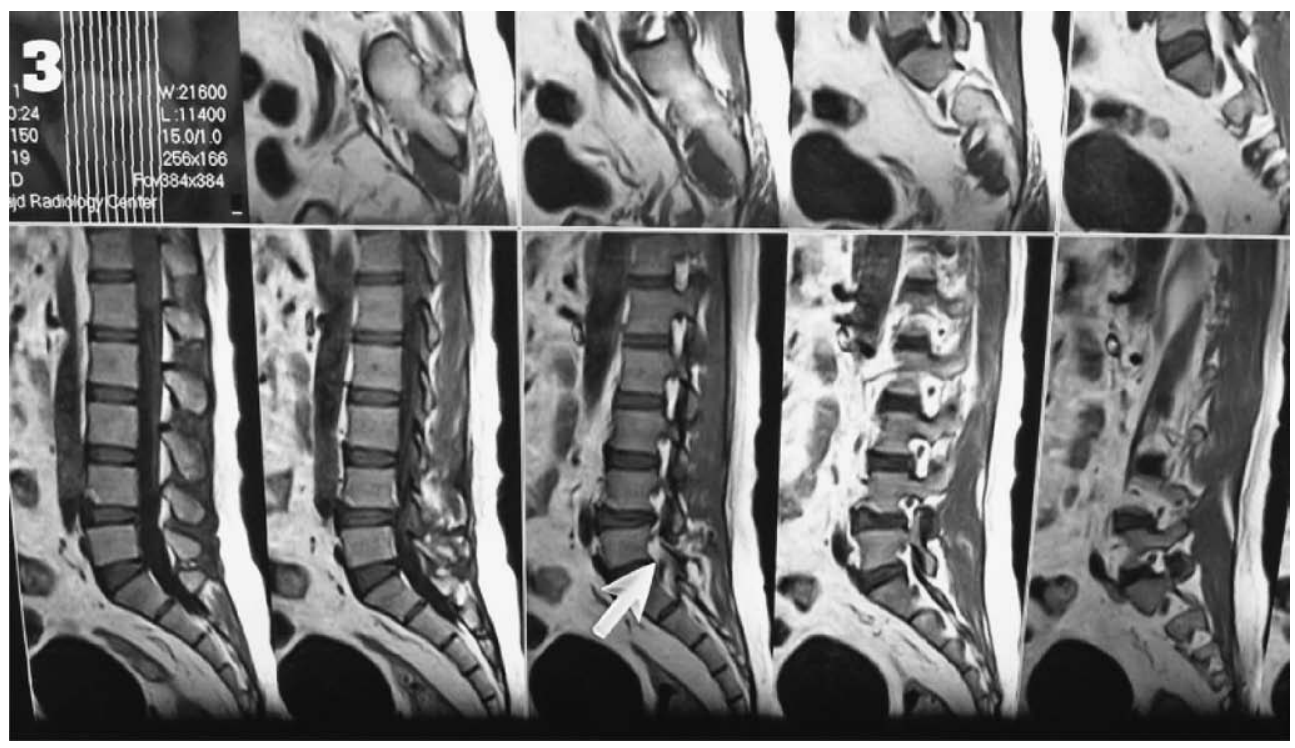

Figure 3: MR Dorso-lumbar spine with contrast Sagittal cuts, showing granulation tissue (arrow) creeping across the thecal sac and inseparable from CM and the distal thecal nerves. 
tions for spinal GBM. Some authors recommend focal spine radiotherapy and chemotherapy with temozolomide, others recommend additional whole-brain radiation even in the absence of intracranial dissemination, while few authors suggest co-administration of intrathecal interferon- $\beta$ and focal spine radiotherapy. Due to the absence of a consensus between studies regarding the therapeutic regimen in addition to the limited data available, the treatment regimen in our case consists of total cordectomy and chemoradiotherapy.

Marchan and his colleagues (8), strongly recommend surgery as a reasonable option when the lesion is in the lower lumbar spine or sacral segments and also in patients with concomitant complete paraplegia and sensory loss to prevent disease dissemination from the original cord lesion. According to their conclusion and our patient clinical scenario, we proceeded with total cordectomy. However, complete resection without causing significant neurological deficit remains practically impossible.

In Singh and his colleagues (5) study, the addition of whole-brain radiotherapy as a treatment option to spinal radiotherapy was explained to be due to the large size of the cervical lesion and juxtaposition of the tumor to the phrenic nerve nucleus which rendered the surgery difficult and challenging. This was not the scenario in our case, so we proceeded with focal spine radiotherapy with temozolomide as an oral chemotherapeutic agent, which has been proved to reduce the tumor size (5).

Despite all of the above, aggressive therapeutic measures, the overall survival remains short in these patients, ranging between $6-16$ months (4) with a median overall survival of 15 months (8). In agreement with these results, our patient experienced local recurrence 15 months postoperatively.

In the review of literature done by Strik and his colleagues (6) regarding the prognosis of all spinal GB cases, only two studies are similar to ours in which cases experienced local recurrence leading to mortality, while the rest of studies reported meningeal seedling and/or cerebral metastases as causes of mortality. Moreover, only $1 / 3$ of the reported patients experienced long-term survival (over 18 months), but the median survival time remains similar to our case report (15 months).

\section{CONCLUSION}

Primary dorso-lumbar GBM with the previous clinical characteristics is a rare finding. While most Spinal GBM cases and previous literature describe treatment with focal spine radiotherapy and chemotherapy, the novelty in our case is the treatment with surgery (total cordectomy) and chemoradiotherapy which lead to a relatively longer overall survival. Despite the total cordectomy and chemoradiotherapy treatment, recurrence occurred within a short time and with poor prognosis.

\section{REFERENCES}

1. Stark AM, Nabavi A, Mehdorn HM, Blömer U. Glioblastoma multiforme-report of 267 cases treated at a single institution. Surg Neurol. 2005;63(2):162-9. doi:10.1016/j.surneu.2004.01.028

2. Shen C, Wu J, Zhao W, Cai Z, Cai R, Chen C. Primary spinal glioblastoma multiforme. Medicine (Baltimore). 2017;96(16):1-6. doi:10.1097/MD.0000000000006634

3. Asano N, Kitamura K, Seo Y, Mukai K, Soga T, Hondo $\mathrm{H}$, et al. Spinal cord glioblastoma multiforme with intracranial dissemination--case report. Neurol Med Chir (Tokyo). 1990;30(7):489-94. doi:10.2176/nmc.30.489

4. Morais N, Mascarenhas L, Soares-Fernandes JP, Silva A, Magalhães Z, et al. Primary spinal glioblastoma: A case report and review of the literature. Oncol Lett. 2013;5(3):992-6. doi:10.3892/ol.2012.1076

5. Singh PK, Singh VK, Tomar J, Azam A, Gupta S, Kumar S. Spinal glioblastoma multiforme: Unusual cause of post-traumatic tetraparesis. J Spinal Cord Med. 2009;32(5):583-6. doi:10.1080/10790268.2009.11754565

6. Strik HM, Effenberger O, Schafer O, Risch U, Wickboldt J, Meyermann R. A case of spinal glioblastoma multiforme: immunohistochemical study and review of the literature. J Neurooncol. 2000;50(3):239-43. doi: 10.1023/A:1006415703881

7. Hernández-Durán S, Bregy A, Shah AH, Hanft S, Komotar RJ, Manzano GR. Primary spinal cord glioblastoma multiforme treated with temozolomide. J Clin Neurosci. 2015;22(12):1877-82. doi: 10.1016/j. jocn.2015.04.017

8. Marchan EM, Sekula RF, Jannetta PJ, Quigley MR. Long-term survival enhanced by cordectomy in a patient with a spinal glioblastoma multiforme and paraplegia. J Neurosurg Spine. 2007;7(6):656-9. doi: 10.3171 /SPI-07/12/656

Corresponding author: Wael Ibrahim, Department of Neurology, Faculty of Medicine, Cairo University, 37 Elhassan Street, Dokki, Giza, Egypt.e-mail:dr.wael_ezzat@hotmail.com 